\title{
Dissolution Behavior of Fluorine from AOD Slag after Treatments for Volume Stabilization
}

\author{
Qixing Yang ${ }^{1, a}$, Anjun $\mathrm{Xu}^{2, \mathrm{~b}}$, Fredrik Engström ${ }^{3, \mathrm{c}}$, Fenglan $\mathrm{Han}^{4, \mathrm{~d}}$, Peng Xue $\mathrm{X}^{5, \mathrm{e}}$, \\ Dongfeng $\mathrm{He}^{6, \mathrm{f}}$, and Bo Björkman ${ }^{7, g}$
}

${ }^{1,3,7}$ MiMeR - Minerals and Metallurgical Research Laboratory, Luleå University of Technology, SE-971 87, Luleå, Sweden

2, 5, 6 Department of Ferrous Metallurgy, School of Metallurgical and Ecological Engineering, University of Science and Technology Beijing, USTB, 100083 China

${ }^{4}$ School of Material Science \& Engineering, Beifang University of Nationality, Yinchuan, Ningxia 750021, China

aqixing.yang@ltu.se, ${ }^{b}$ anjunxu@126.com, ${ }^{\text {c fredrik.i.engstrom@ltu.se, }{ }^{d} 625477897 @ q q . c o m, ~}$ exuepengustb@163.com, ${ }^{\mathrm{f}}$ hdfcn@163.com, ${ }^{9}$ Bo.Bjorkman@ltu.se

Keywords: Fluorine, AOD, Slag, $\mathrm{C}_{2} \mathrm{~S}$, Leaching, Granulation, Stabilization, Immobilization

\begin{abstract}
AOD slag samples from steel works of Outokumpu Stainless Company were used to study F-dissolution relating to treatments for volume stabilization. Results from the slag tests and sample characterizations indicate that the slag re-melting with or without reduction and granulation with either water or gas have rather small effects on $\mathrm{F}$ leaching, as well as formation of different $\mathrm{C}_{2} \mathrm{~S}$ polymorphs. The chemical composition and cooling condition are the two important parameters to control $\mathrm{F}$ leaching from slag samples. These two parameters should be combined together in an optimum way by the steel industry to treat slags for F-immobilization.
\end{abstract}

\section{Introduction}

At a steel plant of Outokumpu Stainless Company, there is an AOD (Argon Oxygen Decarburization) converter of 100-ton capacity used to refine steel melt from an EAF (Electric Arc Furnace) for production of stainless steel. After the refining, slag around 10 tons is tapped out from the converter. A natural cooling of the tapped AOD slag often leads to a slag disintegration or dusting. Fines from the slag disintegration are often difficult to handle or use as materials for construction [1]. It is thus important to prevent the slag dusting in order to facilitate slag handling and utilization.

The disintegration of AOD slag is related mainly to the formation of $\gamma$ phase of dicalcium silicate, $\gamma-\mathrm{Ca}_{2} \mathrm{SiO}_{4}$, abbreviated as $\gamma-\mathrm{C}_{2} \mathrm{~S}$ [1]. Several authors of the present article from the Minerals and Metallurgical Research Laboratory, Luleå University of Technology, LTU, have carried out research work together with the steel company in order to prevent the $\gamma-\mathrm{C}_{2} \mathrm{~S}$-driven slag dusting. Samples of the AOD slag were modified by different cooling techniques [2] and stabilizing agents [3]. Due to the modifications, the AOD slag samples gained the volume stability and mechanical properties required for its utilization as materials for construction [2, 3].

J. Savolainen et al. have made efforts to manufacture environmentally sound and ce-marked construction materials using different types of stainless steel slag from Outokumpu Stainless Company [4]. The authors found that a fast cooling of some AOD slag samples via gas granulation has led to a higher fluorine leaching.

Fluorite can be used as a slag forming agent in other steelmaking processes, such as hot metal pretreatment, secondary steel refining and the production of high alloyed steels. The slags from these processes can contain some amounts of $\mathrm{CaF}_{2}$. A potential fluorine contamination to the ground water may occur, when these slags are utilized as road construction or landfill materials [5-7].

Ryo INOUE et al [5] reported that dicalcium silicate, $\mathrm{C}_{2} \mathrm{~S}$, could dissolve up to 6 mass $\%$ of $\mathrm{F}$ and identified $\mathrm{C}_{2} \mathrm{~S}$ as a main F-containing mineral in hot metal pretreatment and BOF slags. The dissolved 
fluorine from the hot metal pretreatment and secondary refining slags can be immobilized via an incorporation of $\mathrm{F}$ into precipitated hydrates such as $\mathrm{CaO}-\mathrm{Al}_{2} \mathrm{O}_{3}-\mathrm{H}_{2} \mathrm{O}$ and $\mathrm{CaO}-\mathrm{SiO}_{2}-\mathrm{Al}_{2} \mathrm{O} 3-\mathrm{H}_{2} \mathrm{O}$ compounds $[6,7]$.

The $\mathrm{C}_{2} \mathrm{~S}$ forms when values of $\mathrm{CaO} / \mathrm{SiO}_{2}$ for slags exceed 1.4 [1]. For the AOD slag, the values are often close to 2 and the $\mathrm{C}_{2} \mathrm{~S}$ is a predominant slag mineral, which can form solid solution with $\mathrm{CaF}_{2}$ [5]. Thus the $\mathrm{C}_{2} \mathrm{~S}$ in the AOD slag may associate with both the $\gamma-\mathrm{C}_{2} \mathrm{~S}$-driven slag dusting and the $\mathrm{F}$ leaching.

J. Savolainen et al. performed plant slag granulation trails for a better control of $F$ leaching from AOD slag [4]. Early work on the AOD slag carried out by some of the present authors aimed mainly at the dusting prevention $[2,3]$. The present work is thus undertaken to investigate dissolution behavior of $\mathrm{F}$ from AOD slag treated for dusting prevention and by the plant slag granulation.

Laboratory slag tests are performed using slag samples from the early studies $[2,3]$ and the plant tests [4]. Results obtained are discussed together with data from early work [2-4], as well as related literature information [5-7]. The stainless steel industry may be able to use these results for slag treatments, thus producing some slag products with high volume stability and minimum F-dissolution for use in construction to save valuable natural resources.

\section{Experimental}

Plant Gas Granulation Tests of AOD Slag. A granulation facility placed in slag yard at one of the steel works of Outokumpu Stainless Company was used for gas granulation tests of the AOD slag [4, 8]. Liquid slag in the pot from the AOD shop was taken by slag dippers of 2-3 meters long and poured into the facility for granulation using either air or $\mathrm{N}_{2}$ gas with flow rate of $4-5 \mathrm{Nm}^{3} / \mathrm{min}$. Slag granules weighing about $10 \mathrm{~kg}$ were obtained from each of the tests. The slag solidified inside the slag dippers was taken as reference samples.

Slag Tests Performed by the Minerals and Metallurgical Research Laboratory at LTU. Samples from 3 of the gas granulation tests at the steel work of Outokumpu Stainless Company were supplied to LTU for laboratory slag tests with internal sample code AT1, AT2 and AT3. Two AOD slag samples taken from slag yard were supplied by another steel work of the Company for the tests by LTU. The slag sample coded as MA3 has been used for early tests of water granulation [2]. Another sample with code AM4 was crushed and sieved to obtain a sample with size of $-0.85 \mathrm{~mm}$, which was melted together with stabilizers containing B and $\mathrm{P}$ elements for crystal chemical stabilization of high temperature $\mathrm{C}_{2} \mathrm{~S}$ polymorphs [3].

The tests at LTU consisted of slag re-melting and treatments with different methods. There was some reduction of slag while it was contained in graphite crucibles for the re-melting. The reduction was avoided by using $\mathrm{MgO}$ crucibles to hole the samples.

The graphite/MgO crucible and an outer refractory crucible formed a crucible system that was inserted in the induction coil, which was connected to a power generator of $60 \mathrm{~kW}$ and $3 \mathrm{kHz}$. The temperature increased from around $20^{\circ} \mathrm{C}$ to $1600^{\circ} \mathrm{C}$ with heating rates of $3.6-5^{\circ} \mathrm{C} /$ minute and heating periods often more than 7 hours to re-melt slag samples in $\mathrm{MgO}$ crucibles. After maintaining the temperature of $1600^{\circ} \mathrm{C}$ for $10-30$ minutes, the furnace power was switched off and each of the slag samples left in $\mathrm{MgO}$ crucible to cool to room temperature in the closed furnace. The in-furnace cooling took about 5 hours, giving slow cooled slag samples. Some other details about the slag re-melting can be found in $[2,3]$.

Fig. 1A shows the system for water granulation of AOD slag sample MA3. For re-melting the sample using graphite crucible, the heating time was around 1 hour. Shortly after the slag melting, a crucible holder was used to grasp the outer refractory crucible for placing the crucible system ( 3 in Fig. 1) above the slag granulation system. The liquid slag (4 in Fig. 1) about $1550^{\circ} \mathrm{C}$ was tapped through the granulation device ( 2 in Fig. 1 ) and hit by water jets to generate slag granules, which fell down into the water tank (1 in Fig.1). Other details about the granulation system can be found in [2]. 
Fig. 1B shows the granulation system for AOD slag sample MA4. The furnace (5 in Fig. 1) was tilted to pour the liquid slag of $1700^{\circ} \mathrm{C}$ out of the graphite crucible. An injector (6 in Fig. 1) under the furnace started to inject air of pressure 3 bars into the granulation box ( 7 in Fig. 1). Slag granules ( 8 in Fig. 1) generated by air jet, after flying briefly, fell to and cooled on the box base.

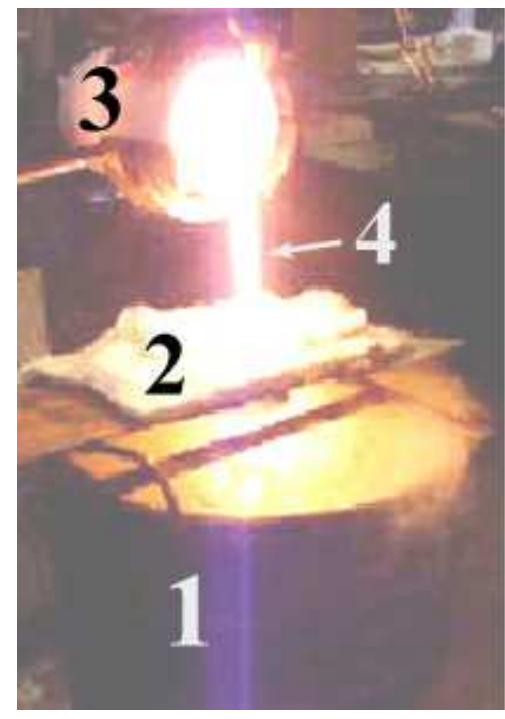

A.

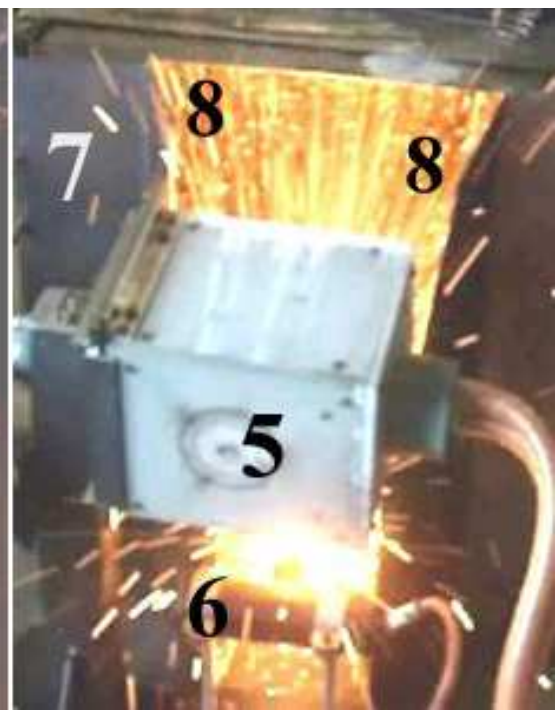

B.

Fig. 1 - A. System for water granulation of the re-melt/reduced and re-melt AOD slag sample MA3, B. System for air granulation of re-melt/reduced AOD slag sample AM4; in the figure: 1. Water tank, 2. Granulation Device, 3. Crucible system for slag melting and tapping, 4. Liquid slag for granulation, 5. Induction furnace tilted to pour liquid slag out of the graphite crucible, 6 . Air injector, 7. Granulation box, 8. Slag granules flying in the box

Slag samples were analyzed by the analytical laboratory of Outokumpu Stainless Company using XRF method. Leaching tests were performed with SS EN 12457-2 for slag samples from laboratory tests and with SS EN 12457-3 for slag samples from the plant trails of gas granulation [4].

\section{Experimental results and discussion}

Oxide contents in slag samples from laboratory tests and plant trails are listed in Table 1. Table 2 presents results of $\mathrm{F}$ leaching from MA3 and MA4 samples before and after laboratory tests. The original sample MA3-0 leached F of $89 \mathrm{mg} / \mathrm{kg}$. The upper XRD pattern in Fig. 2 shows that phase 4 or $\mathrm{Ca}_{3} \mathrm{Al}_{2} \mathrm{O}_{6}$, with rather high peaks, is one of the major phases in the sample MA3-3. This phase may contribute to decreasing F-leaching from MA3-3 to the very low value, $0.001 \mathrm{mg} / \mathrm{kg}$, Table 2 , as the phase can form F-containing hydrate $\mathrm{Ca}_{3} \mathrm{Al}_{2}(\mathrm{H}, \mathrm{F})_{12}[5,6]$. By the slow cooling in crucible a higher amount of $\mathrm{Ca}_{3} \mathrm{Al}_{2} \mathrm{O}_{6}$ can form to decrease $\mathrm{F}$ dissolved from MA3-3 sample.

There are rather large decreases in heights of peaks for the $\mathrm{Ca}_{3} \mathrm{Al}_{2} \mathrm{O}_{6}$ phase near $2 \theta$ of $48^{\circ}$ in the lower XRD pattern of Fig. 2, indicating a limited formation of the mineral in MA3-1. The sample MA3-1 and MA3-2 were from the granulation and the liquid slag was quickly cooled by water jets, leaving little or no time for $\mathrm{Ca}_{3} \mathrm{Al}_{2} \mathrm{O}_{6}$ to precipitate or solidify out of the liquid slag to the amount necessary for F-stabilization. Thus a high amount of F, 215 and $255 \mathrm{mg} / \mathrm{kg}$, was dissolved, respectively, from MA3-1 and MA3-2 samples, Table 2.

The original MA4 sample leached $18.6 \mathrm{mg} / \mathrm{kg}$ of F. After re-melted together with $0.5 \%$ Dehybor and in-furnace cooled [3], F leaching from sample MA4-1 increased somewhat to $37 \mathrm{mg} / \mathrm{kg}$. However, F leaching from MA4-2 increased sharply to $152 \mathrm{mg} / \mathrm{kg}$, after it was granulated by air. Though F content is $2.4 \%$ in MA4-2, lower than F content of 3.37\% in MA4-1, Table 1. 
Table 1 Contents [weight \%] of analyzed oxides in the AOD slag samples, $\mathrm{B}_{2}=\mathrm{CaO} / \mathrm{SiO}_{2}$

\begin{tabular}{|l|c|c|c|c|c|c|c|c|c|}
\hline & $\mathrm{F}$ & $\mathrm{SiO}_{2}$ & $\mathrm{CaO}$ & $\mathrm{Al}_{2} \mathrm{O}_{3}$ & $\mathrm{MgO}$ & $\mathrm{FeO}$ & $\mathrm{MnO}$ & $\mathrm{TiO}_{2}$ & $\mathrm{~B}_{2}$ \\
\hline MA3-0 & 2.40 & 25.2 & 53.0 & 6.0 & 5.2 & 1.50 & 0.5 & 0.43 & 2.1 \\
\hline MA3-1 & 2.40 & 26.2 & 55.9 & 9.1 & 6.4 & 0.70 & 0.8 & 1.08 & 2.13 \\
\hline MA3-2 & 2.20 & 22 & 49.5 & 7.6 & 5.8 & 1.50 & 0.7 & 0.75 & 2.25 \\
\hline MA3-3 & 2.30 & 26.1 & 53.3 & 6.4 & 5.6 & 0.40 & 0.9 & 0.88 & 2.04 \\
\hline MA4-0 & 2.05 & 30.8 & 57.7 & 1.6 & 4.8 & 0.45 & 0.8 & 0.37 & 1.87 \\
\hline MA4-1 & 3.37 & 30.8 & 54.5 & 2.2 & 5.9 & 0.9 & 1.2 & 0.66 & 1.77 \\
\hline MA4-2 & 2.40 & 30.1 & 49.1 & 2.4 & 5.6 & 0.2 & 0.9 & 0.59 & 1.63 \\
\hline AT1 & 0.44 & 26.8 & 34.5 & 8.5 & 14.5 & 0.5 & 1.4 & 2.42 & 1.29 \\
\hline AT2 & 3.13 & 27.8 & 50.3 & 1.1 & 8.5 & 0.3 & 0.3 & 0.5 & 1.81 \\
\hline AT3 & 1.52 & 28.3 & 47.4 & 4.3 & 9 & 0.3 & 0.6 & 0.6 & 1.68 \\
\hline
\end{tabular}

Table 2 F leaching from slag samples MA3 [2] and MA4 [3] tested at LTU

\begin{tabular}{|c|c|c|}
\hline Sample & Laboratory treatments for the samples & F leaching, $[\mathrm{mg} / \mathrm{kg}]$ \\
\hline MA3-0 & Original MA3 sample & 89 \\
\hline MA3-1 & MA3 with reduction/re-melting and water granulation & 215 \\
\hline MA3-2 & MA3 with re-melting and water granulation & 255 \\
\hline MA3-3 & MA3 with reduction/re-melting and cooling in crucible & 0.001 \\
\hline MA4-0 & MA4 after metal separation with size $<0.85 \mathrm{~mm}$ & 18.6 \\
\hline MA4-1 & MA4 re-melted with 0.5\% Dehybor & 37 \\
\hline MA4-2 & $\begin{array}{c}\text { MA4 after reduction/re-melting and air granulation with } \\
\text { size }<1.7 m m\end{array}$ & 152 \\
\hline
\end{tabular}

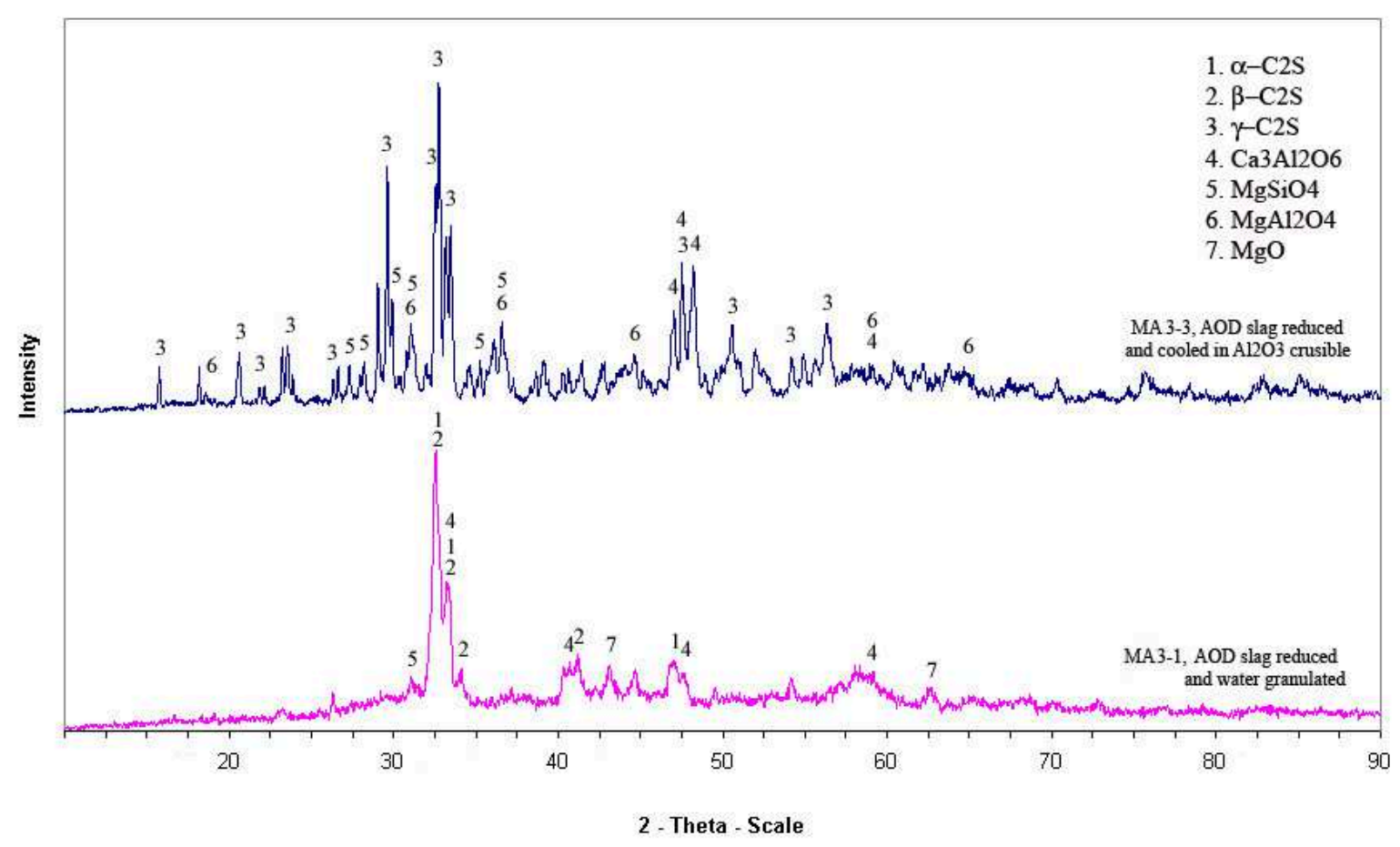

Fig. 2 - XRD patterns of sample MA3-3, upper pattern, and MA3-1, the lower pattern

The 3 reference samples from the plant trails leached $\mathrm{F}$ of $80-111 \mathrm{mg} / \mathrm{kg}$, which were lower by $80-160 \mathrm{mg} / \mathrm{kg}$ than the samples from the gas granulation, Table 3. SEM and EDS analyses of a sample from granules AT3 in Fig. 3 show two nearly round crystals with spectrum 1 and 2, which have $\mathrm{Ca} / \mathrm{Si}$ 
value 1.76 and low contents of $\mathrm{Al}, \mathrm{Cr}$ and $\mathrm{Mn}$, see the table below the SEM micrograph of Fig. 3. The matrix zones with spectrum 3-5 have higher contents of $\mathrm{Al}, \mathrm{Cr}, \mathrm{Mn}$ and $\mathrm{Mg}$, but lower $\mathrm{Ca} / \mathrm{Si}$ values of 1.6-1.67.

The minerals in matrix zones may be formed at lower temperature. While in contact with water, the matrix minerals, with weaker structures and larger specific surface areas, may dissolve higher amounts of their internal substances, including $\mathrm{F}$ element. The two round crystals with less specific surface area and stronger structures can be more resistant to the leaching.

Table $3 \mathrm{~F}$ leaching from slag samples AT1, AT2 and AT3 from the plant gas granulation [4] and laboratory tests of re-melting and in-furnace cooling

\begin{tabular}{|c|c|c|c|}
\hline \multirow{2}{*}{ Test sample } & \multicolumn{3}{|c|}{ F leaching from slag samples after treatments, [mg/kg] } \\
\cline { 2 - 3 } & Plant trails of gas granulation & $\begin{array}{c}\text { Laboratory tests of granule } \\
\text { re-melting and in-furnace cooling }\end{array}$ \\
\hline AT1 & 80.6 & 263 & 9.5 \\
\hline AT2 & 110 & 191 & 151 \\
\hline AT3 & 111 & 251 & 208 \\
\hline
\end{tabular}

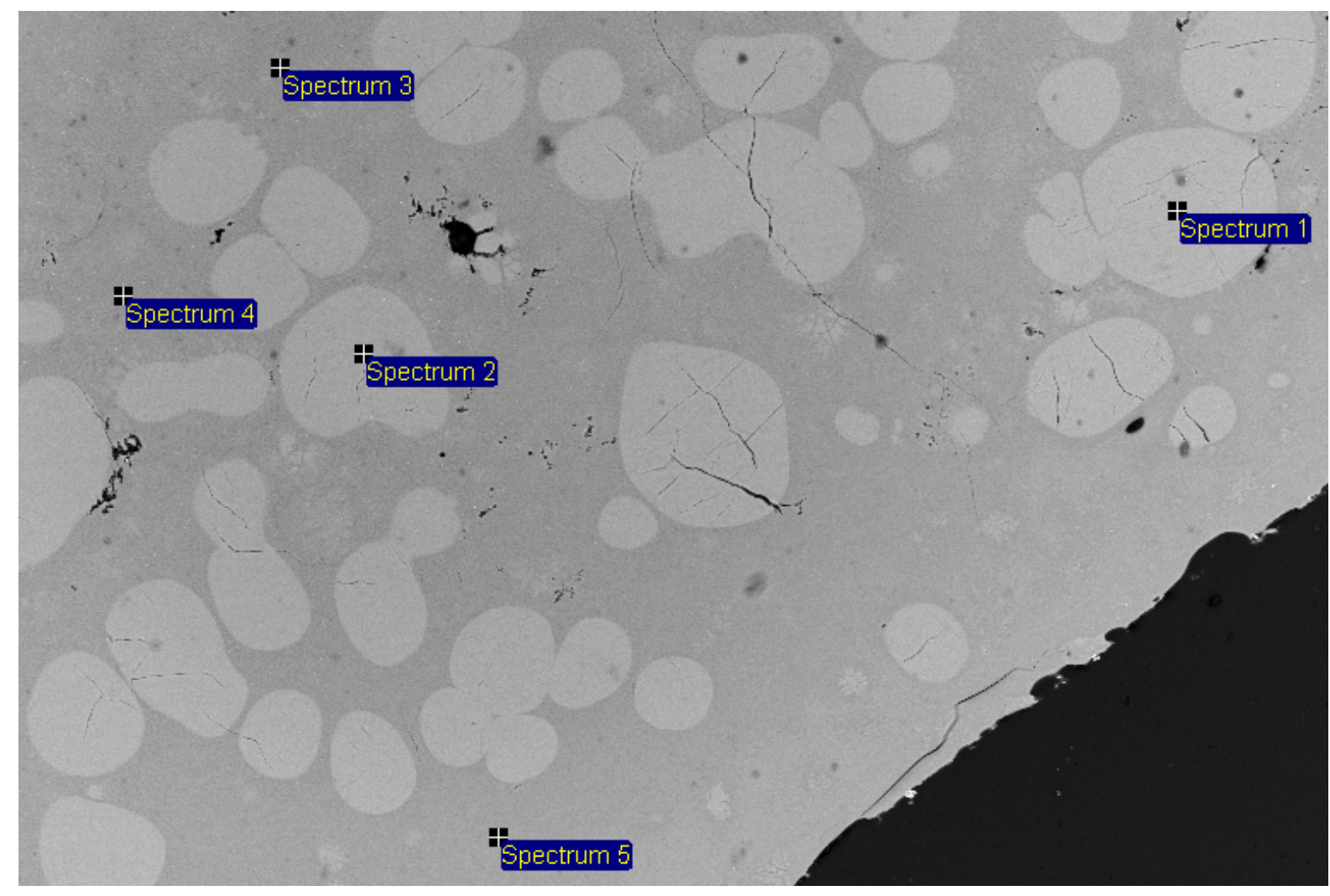

\begin{tabular}{|l|c|c|c|c|c|c|c|c|c|}
\hline & $\mathrm{F}$ & $\mathrm{Mg}$ & $\mathrm{Al}$ & $\mathrm{Si}$ & $\mathrm{Ca}$ & $\mathrm{Cr}$ & $\mathrm{Mn}$ & $\mathrm{O}$ & $\mathrm{Ca} / \mathrm{Si}$ \\
\hline Spectrum 1 & & 1.8 & & 14.8 & 25.9 & 0.08 & 0.08 & 57.4 & 1.75 \\
\hline Spectrum 2 & & 1.4 & & 14.9 & 26.2 & 0.08 & & 57.5 & 1.76 \\
\hline Spectrum 3 & 2.18 & 6.2 & 2.7 & 12.1 & 19.4 & 0.58 & 0.28 & 56.1 & 1.61 \\
\hline Spectrum 4 & 3.2 & 5.0 & 1.5 & 13.1 & 21.0 & 0.15 & 0.18 & 55.6 & 1.60 \\
\hline Spectrum 5 & 4.35 & 6.0 & 2.6 & 11.7 & 19.5 & 0.36 & 0.29 & 54.7 & 1.67 \\
\hline
\end{tabular}

Fig. 3 SEM micrograph and point analyses, in [atom\%], by EDS of a sample from granules AT3 
The crystals with $\mathrm{Ca} / \mathrm{Si}$ value near 2 may be $\mathrm{C}_{2} \mathrm{~S}$ particles, which can dissolve up to $6 \%$ of $\mathrm{F}$ [5]. However, $\mathrm{F}$ element was not detected in the $\mathrm{C}_{2} \mathrm{~S}$ crystals, rather, was concentrating in the matrix minerals with contents of 2.18-4.35\%, which may be one of the reasons for the higher F leaching from the granule samples from the plant trails. More studies may be needed to clarify influences of cooling and other factors on F-enrichment in the matrix.

A sample from AT1, the granules from the plant trails with F leaching of $263 \mathrm{mg} / \mathrm{kg}$, after laboratory treatments of re-melting and in-furnace cooling, leached much less $\mathrm{F}$ of $9.5 \mathrm{mg} / \mathrm{kg}$. Whereas, for samples of granules AT2 and AT3 with the same laboratory treatment, F leaching decreased moderately by only around $40 \mathrm{mg} / \mathrm{kg}$, Table 3 . The different results for the 3 granule samples treated in the same way may be related to differences in oxide contents.

For granules AT1 the $\mathrm{B}_{2}\left(\mathrm{CaO} / \mathrm{SiO}_{2}\right)$ value is 1.29 , the lowest, and contents of $\mathrm{Al}_{2} \mathrm{O}_{3}$ of $8.5 \%$ and $\mathrm{MgO}$ of $14.5 \%$ are the highest as compared with AT2 and AT3, Table 1. These will result in different temperature levels for slag solidification under the same cooling condition. With a lower temperature level there may be a longer time for some mineral phases to precipitate from the liquid slag. The re-melted granules AT1 may have a longer solidification time, which, together with its higher $\mathrm{Al}_{2} \mathrm{O}_{3}$ content, may facilitate the $\mathrm{Ca}_{3} \mathrm{Al}_{2} \mathrm{O}_{6}$ formation and, hence, a sharp decrease in the $\mathrm{F}$ leaching. Besides, $\mathrm{F}$ content is $0.44 \%$ in granules AT1, lower than the two granules with $\mathrm{F}$ contents of $1.52-3.13 \%$, which may make the laboratory treatment more effective to decrease $\mathrm{F}$ leaching from AT1 granules.

The granules AT2 and AT3 may be solidified faster with their high $\mathrm{B}_{2}$ values, 1.81 and 1.68, respectively, leaving short time for the $\mathrm{Ca}_{3} \mathrm{Al}_{2} \mathrm{O}_{6}$ to precipitate. With lower $\mathrm{Al}_{2} \mathrm{O}_{3}$ contents of $1.1 \%$ and $4.3 \%$, Table $1, \mathrm{Al}_{2} \mathrm{O}_{3}$ available for the $\mathrm{Ca}_{3} \mathrm{Al}_{2} \mathrm{O}_{6}$ to form were also limited. Thus, the amounts of $\mathrm{Ca}_{3} \mathrm{Al}_{2} \mathrm{O}_{6}$ formed may not be sufficient for a high degree of F-immobilization. Consequently, the decreases in F leaching for the re-melted granules AT2 and AT3 are quite moderate.

The results in Tables 1-3 demonstrate that the re-melting and granulation conditions have rather small effects on $\mathrm{F}$ leaching, as well as the phase transformation of $\mathrm{C}_{2} \mathrm{~S}$ in the slag. The leaching of $\mathrm{F}$ may be controlled mainly by the chemical composition of the slag samples and cooling condition for the treatments. These factors should be adjusted together in an optimum way to treat a slag for its $\mathrm{F}$ immobilization.

It is also recommended to decrease amounts of $\mathrm{CaF}_{2}$ containing materials for slag forming. Some researchers have successfully replaced fluoride with some new F-free catalyzers for $\mathrm{MgO}$ reduction in Pidgeon process [9]. Some similar efforts may also be made to develop new techniques of F-free slag forming for the steel industry to manufacture high quality steel and slag products, thereby protecting the environment and saving valuable natural resources.

\section{Summary}

Samples of AOD slag after tapping and gas granulation at steel works of Outokumpu Stainless Company were tested using laboratory equipment to study F-dissolution relating to treatments of the slag samples for volume stabilization, achieving the following results:

1. The AOD slag samples cooled slowly in plant trails or in laboratory furnaces leached moderate amounts of fluorine. The F leaching was enhanced to $150-260 \mathrm{mg} / \mathrm{kg}$ from slag samples with high speed cooling via water and gas granulation.

2. XRD detected $\mathrm{Ca}_{3} \mathrm{Al}_{2} \mathrm{O}_{6}$ as a major phase in a slag sample with in-furnace cooling. The phase immobilized fluorine effectively, leading to a very low F leaching of $0.001 \mathrm{mg} / \mathrm{kg}$. However, a fast cooling by water granulation limited extent of $\mathrm{Ca}_{3} \mathrm{Al}_{2} \mathrm{O}_{6}$ formation, resulting in higher amounts of $F$ leaching from the slag samples.

3. SEM and EDS studies of granules from a plant granulation trail show round crystals containing no $\mathrm{F}$ element. $\mathrm{F}$ element was observed mainly in the matrix zones, ranging $2.18-4.35 \%$. The gas granulation may lead to an F-enrichment in matrix minerals with weaker 
structures and larger specific surface areas. The matrix may easily dissolve, releasing $\mathrm{F}$ from the granules.

4. While being treated by re-melting and in-furnace cooling after the granulation, the granule samples with lower $\mathrm{CaO} / \mathrm{SiO}_{2}$ values and higher $\mathrm{Al}_{2} \mathrm{O}_{3}$ contents may gain longer time for formation of $\mathrm{Ca}_{3} \mathrm{Al}_{2} \mathrm{O}_{6}$ phase, giving a higher degree of $\mathrm{F}$-immobilization.

5. Results from the present study indicate that the slag re-melting with or without reduction and granulation with either water or gas have very limited effects on F leaching, as well as the formation of different $\mathrm{C}_{2} \mathrm{~S}$ polymorphs. The chemical composition and cooling condition are the two important parameters to control $\mathrm{F}$ leaching from slag samples. These two parameters should be combined together in an optimum way to treat the slag for F-immobilization.

\section{Acknowledgements}

The authors wish to thank the Foundation for Strategic Environmental Research, Mistra (the steel Eco-Cycle) and CAMM, Center for Advanced Mining and Metallurgy, LTU, for financial support, as well as colleagues and the staffs of Outokumpu Stainless Company for their support and assistance. During the time of research visiting at LTU, Peng Xue and Dongfeng He have been supported financially by CAMM at LTU and CSC, Chinese Scholarship Council, and USTB, which is gratefully acknowledged.

\section{References}

[1] A. Seki, Y. Aso, M. Okubo, F. Sudo, K. Ishizaka: KAWASAKI STEEL TECHNICAL REPORT No. 15, p. 16, October (1986)

[2] Qixing Yang, F. Engström, M. Tossavainen and D. Adolfsson: in Proceedings of SECURING THE FUTURE, International Conference on Mining and the Environment, Metals and Energy Recovery, Skellefteå, SWEDEN, June 27-July 1, (2005)

[3] Qixing Yang, L. Nedar, F. Engström and Mingzhao He: in Proceedings of The Iron \& Steel Technology Conference, AISTech 2006, Cleveland, Ohio, USA. Volume 1, p. 573, May 1-4, (2006)

[4] J. Savolainen,T. Parviainen and J. Roininen: in Proceedings of 6th European Slag Conference, 20-22, October 2010, Madrid

[5] Ryo INOUE and Hideaki SUITO, ISIJ International, Vol. 42, No. 7, (2002), p. 785

[6] Hideaki SUITO and Ryo INOUE, ISIJ International, Vol. 42, No. 8, (2002), p. 921

[7] Hongye HE and Hideaki SUITO, ISIJ International, Vol. 42, No. 7, (2002), p. 794

[8] MEFOS internal rapport: MEF08002KC

[9] Fenglan Han, Qixing Yang, Laner Wu and Chun Du, Advanced Materials Research Vol. 690-693, (2013) p 378 
Sustainable Cities Development and Environment Protection IV

10.4028/www.scientific.net/AMM.587-589

Dissolution Behavior of Fluorine from AOD Slag after Treatments for Volume Stabilization 10.4028/www.scientific.net/AMM.587-589.849 